\title{
KRAJOBRAZ PO BREXICIE. POLACY I BRYTYJCZYCY W PROCESIE WZAJEMNEJ AKULTURACJI
}

\author{
Grażyna Czubińska*, Magdalena Łużniak-Piecha***

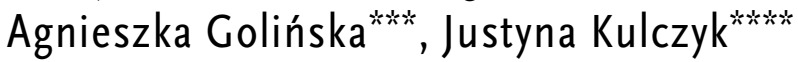

\begin{abstract}
Abstrakt
Artykuł dotyczy skutków brytyjskiej decyzji o odłączeniu się od UE. Temat ujęto z punktu widzenia psychologii międzykulturowej, opisując Brexit w kontekście wiedzy na temat mechanizmów psychologicznych, stojących za tak ekstremalnym przypadkiem swoistej strategii „budowania” stosunków międzykulturowych. Celem opracowania jest wskazanie na ważny moment ewolucji procesów akulturacyjnych we współczesnej Europie. Analizujemy przyczyny wyboru podjętego w Wlk. Brytanii oraz czynniki kolejnego wyboru: między odejściem a pozostaniem Polskich emigrantów i rodzin emigracyjnych w Wielkiej Brytanii. Tekst ma formę przeglądową, z odwołaniem do badań własnych.
\end{abstract}

Słowa kluczowe: wzajemna akulturacja, Brexit, psychologia międzykulturowa, Relative Acculturation Extended Model

\section{BREXIT AFTERMATH.}

\section{Poles and Britons in the Process of Mutual Acculturation}

\begin{abstract}
Acculturation processes as complex and multidimensional are analyzed towards different domains, different fields in which both cultures change e.g. political, work, economic, family, social, religion... In all those fields it is important to search for solutions helping to incorporate immigrants in their new societies and allow effective coexistence between majorities and minorities. To analyze post-Brexit concerns of such nature among Polish immigrants, Psychologists from Polish University Abroad in London (PUNO) designed a research program: "Poles in Britain during Brexit."
\end{abstract}

Keywords: mutual acculturation, Brexit, cross-cultural psychology, Relative Acculturation Extended Model

\footnotetext{
*Dr Grażyna Czubińska, Polski Uniwersytet na Obczyźnie, Londyn, e-mail: grazyna.czubinska@puno.edu.pl | ORCID: https://orcid.org/ oooo0001-5993-536X; " "\#dr Magdalena Łużniak-Piecha, Uniwersytet SWPS, Warszawa, Polski Uniwersytet na Obczyźnie, Londyn, mail: mluzniakpiecha@swps.edu.p\| ORCID: https://orcid.org/0000-0001-9834-7552; ${ }^{\text {*ærk }}$ mgr Agnieszka Golińska, Tecnologico de Monterrey, Meksyk, Instytut Psychologii, Polska Akademia Nauk, mail: agolinska@swps.edu.pl| ORCID: https://orcid.org/0000-0002-0284-7315; ${ }^{\text {kkmk }} \mathrm{mgr}$ Justyna Kulczyk, Polski Uniwersytet na Obczyźnie, Londyn, mail: justyna.kulczyk@wp.pl| ORCID: https://orcid.org/0000-0002-3394-0758.
} 
Wstęp

23 czerwca 2016 r. Brytyjczycy zdecydowali się wyjść z Unii Europejskiej. Decyzja ta, dla jednych szokująca, dla innych zgodna z przewidywaniami, z całą pewnością jest postanowieniem brzemiennym w skutki nietylko dla samych Brytyjczyków. Rozważania zawarte wprezentowanym artykule skupiają się wokół tematyki dotyczącej skutków brytyjskiej decyzji o odłączeniu się od UE, podjętej podczas ostatniego referendum. Powstało już wiele opracowań politologicznych i socjologicznych, tworzonych przez publicystów oraz analityków z Wielkiej Brytanii, Europy i świata na temat przyczyn i skutków Brexitu (zob. np.: Coleman 2016; Gietel-Basten, 2016; Harris 2016), brakujejednak analizy psychologicznej, zwłaszcza tworzonej z punktu widzenia psychologii międzykulturowej, która opisywałaby Brexit w kontekście wiedzy na temat mechanizmów psychologicznych, stojących za tak ekstremalnym przypadkiem swoistej strategii „budowania” stosunków międzykulturowych.

Celem powyższego opracowania jest wskazanie na niezwykle istotny moment ewolucji procesów akulturacyjnych we współczesnej Europie. Polscy psychologowie praktykujący i prowadzący badania naukowe w Wielkiej Brytanii spotykają się z dość intensywnie wyrażanym zapotrzebowaniem społecznym, dotyczącym eksperckiej opinii w sprawie wyboru podjętego w Wlk. Brytanii; jest to również oczekiwanie na opinię dotyczącą kolejnego wyboru; tym razem wyboru między odejściem a pozostaniem Polskich emigrantów i rodzin emigracyjnych w Wielkiej Brytanii. Wielu Polaków mieszkających obecnie na terenie Zjednoczonego Królestwa zadaje sobie pytanie, które można streścić następująco: „Czy należy zostać wWielkiej Brytanii, wrócić do Polski, czy może trzeba zacząć przygotowywać się na dość szeroko rozumiane zmiany w życiu, na niepewną i niestabilną przyszłość?”

W tym opracowaniu fenomen Brexitu analizowany jest z perspektywy partnerstwa, zaufania, budowania relacji w skali jednostkowej oraz w skali 
dwóch dużych grup kulturowych, wchodzących w skład brytyjskiego społeczeństwa: polskich imigrantów w Wielkiej Brytanii i Brytyjczyków stanowiących grupę większościową. Podstawę teoretyczną prezentowanej analizy stanowi Relatywny Model Względnej Akulturacji (RAEM) autorstwa Marisol Navas at al. (2005). Tekst ma formę przeglądową, z odwołaniem do badań własnych.

\section{Akulturacja jako proces wielowymiarowy}

Bezpośrednią konsekwencją migracji międzynarodowych jest powstawanie społeczeństw składających się z osób o zróżnicowanym pochodzeniu etnicznym i kulturowym. Istotną kwestią analizowaną przez psychologię międzykulturową jest badanie sposobów i strategii, dzięki którym osoby z różnych środowisk kulturowych radzą sobie z codziennymi interakcjami, kształtującymi życie członków takich społeczności. Podstawowym podejściem, przyjmowanym w przypadku budowania analizy psychologicznej relacji międzyludzkich, jest założenie dotyczące analizowania punktu widzenia obu stron danej relacji. Podobnie w przypadku relacji międzykulturowych powinniśmy studiować akulturację psychologiczną, biorąc pod uwagę zarówno grupę gospodarzy, jak i grupy przybyszy (Piontkowski et.al. 2002). Należy też wziąć pod uwagę kontekst społeczny, ekonomiczny i historyczny, w którym rozwijają się te relacje.

Pojęcie akulturacji psychologicznej odnosi się do procesu zmian (dotyczących stylu życia, postaw, tożsamości, wartości itp.), zachodzących w sytuacji wchodzenia w stały kontakt z członkami różnych kultur. Proces ten dotyczy „zmian w osobie, która jest uczestnikiem sytuacji kontaktu z kulturą, na którą wpływ ma bezpośrednio kultura zewnętrzna, a także zmian w kulturze, której dana osoba jest członkiem" (Berry 2005, s. 701). Początkowo akulturacja była konceptualizowana jako proces jednowymiarowy i jednokierunkowy. Zakładano, że zmiany 
występują przede wszystkim w grupach mniejszościowych oraz grupach imigrantów (Horenczyk et al. 2013). Obecnie badacze zgadzają się, że obie grupy, które pozostają w kontakcie, wpływają na siebie nawzajem.

Akulturacja jest procesem obejmującym nie tylko zmiany w stylu życia imigrantów, zachodzące pod wpływem kontaktu ze społeczeństwem goszczącym. Oznacza również, że społeczeństwo przyjmujące zmienia się w obliczu napływu kolejnych grup imigracyjnych. Ten sam proces wzajemnego wpływu i zmian w obu grupach może stać się źródłem budowania silnej gospodarki i otwartego, zaawansowanego cywilizacyjnie, technologicznie i kulturowo społeczeństwa, ale także przyczyną destrukcyjnych tarć kulturowych. Brexit jest analizowany w niniejszym opracowaniu jako zjawisko występujące na tym końcu skali relacji międzykulturowych, który opisuje silne tarcie i zjawiska z zakresu niepowodzenia akulturacyjnego na poziomie społecznym, w odniesieniu do obecnie panującego klimatu psychologicznego na Wyspach.

Procesy akulturacji jako zjawiska złożone i wielowymiarowe są analizowane pod kątem różnych domen, różnych dziedzin, w których obie kultury zmieniają się, jak na przykład obszary polityczne, zawodowe, ekonomiczne, rodzinne, społeczne, religijne, ksztaltowanie postaw i sposobu myślenia (Navas et al. 2005). We wszystkich tych dziedzinach ważne jest poszukiwanie rozwiązań, które wspomagają integrację obcokrajowców w nowych społeczeństwach i pozwolą na skuteczne współistnienie grup większościowych i mniejszościowych. J eśli takie rozwiązania są trudne do znalezienia lub wprowadzenia, wśród członków obu grup może wytworzyć się szczególny klimat emocjonalny: wzajemnej nieufności i uprzedzeń. Stawiamy tezę, iż może to być zjawisko możliwe do zaobserwowania dzisiaj w Wielkiej Brytanii.

Zgodnie z dwuwymiarowymi modelami akulturacji (np. Berry 1990) oraz nowszymi pracami (np. Bourhis et al. 1997; Piontkowski et al. 2002, Navas et al. 2005), różne strategie dotyczące akulturacji można 
wyodrębnić krzyżując w procesie ich analizy dwa wymiary: podtrzymanie własnej kultury i przyjmowaniekultury gospodarza, zarówno dla gospodarzy, jak i dla mniejszości. Krzyżując zatem owe dwa wymiary (podtrzymywanie oraz przyjmowanie) otrzymujemy cztery możliwe strategie akulturacji.

Strategia integracji opiera się na zachowaniu elementów kultury pochodzeniai łączeniu ich z przyjętymi elementami kultury społeczeństwa goszczącego.

Strategia asymilacji zakłada przyjęcie kultury nowego społeczeństwa odrzuciwszy przy tym elementy kultury kraju pochodzenia - częściej spotyka się ją w drugim lub trzecim pokoleniu imigrantów, mających wiedzę na temat kraju pochodzenia dziadków, jednak identyfikujących się z kulturą „nowego” kraju, w którym się urodzili.

Strategia separacji ma miejsce, gdy jednostka odrzuca nową kulturę i jednocześnie pragnie utrzymać wszystkie cechy kultury rodzimej - jest to strategia, która może prowadzić do tworzenia szczególnego rodzaju społeczności typu getto.

Czwarta z możliwych strategii to strategia marginalizacji: preferencja dla nieutrzymywania i nieadoptowania elementów żadnej z dwu kultur, życia poza kulturą, w klasycznych modelach opisywana jako wykluczenie kulturowe i bezdomność kulturowa. Opcja marginalizacji jest zapewne możliwa tylko dla niewielkiej części migrantów (Berry 2006).

Prawdopodobieństwo, że dana jednostka rozwinie poczucie tożsamości kulturowej bez orientacji na którąkolwiek z kultur, wydaje się być bardzo niskie (Schwartz et al. 2010). Nowsze badania opisują jednak taką strategię wśród współczesnych menedżerów-ekspatów, nazywających siebie „obywatelami świata bez kotwicy kulturowej” - tacy ludzie raczej przywiązani są do systemu wartości kultury organizacyjnej wielkiej korporacji niż do poszczególnych tradycji jakiegokolwiek kraju (Łużniak-Piecha, Witkowski 2007). 
Innym możliwym wyjaśnieniem jest to, że niektóre osoby określają siebie i innych jako niezależne jednostki, a nie przez pryzmat kultury pochodzenia; identyfikują się jako jednostki, a nie członkowie określonej grupy narodowej lub kulturowej (Rivera, Burgos 2010).

Według Marisol Navas i współpracowników (2007) preferencje dotyczące wyboru określonej strategii akulturacji zależą od konkretnych obszarów życia i funkcjonowania. Z jednej strony możemy wyróżnić tzw. publiczne obszary życia (peryferyjne z punktu widzenia identyfikacji kulturowej), tj. system polityczny, społeczny dobrostan, praca i związane z nawykami konsumenckimi i gospodarką, z drugiej strony wyróżniamy obszary prywatne (stanowiące jądro identyfikacji kulturowej), tj. bliskie kontakty społeczne, rodzinne, życie religijne i system wartości. W opisywanym tu ujęciu psychologowie podkreślają, iż należy uwzględnić fakt, że członkowie mniejszości i społeczeństwa przyjmujące mogą mieć różne preferencje w zakresie akulturacji w zależności od kontekstu oraz obszaru życia, którego ten proces dotyczy. Na przykład, dana osoba może preferować asymilację (pełne przyjęcie nowych wartości kulturowych) w kontekście pracy, integrację (przyjmowanie nowej kultury, przy zachowaniu własnych wartości kulturowych) w obszarze relacji społecznych, wśród przyjaciół z różnych kultur, oraz separację (utrzymywanie tylko kultury własnej) w obszarze przekonań religijnych oraz wartości. Ta sama osoba może rozwinąć wszystkie te trzy preferencje jednocześnie (Rojas et al. 2007).

Antionio Rojas i Marisol Navas oraz ich współpracownicy (2014) w ramach modelu RAEM stwierdzają równiė̇, że podobnie jak dla preferowanych strategii akulturacji w zależności od obszaru życia (bardziej publicznevs. bardziej prywatne sfery życia), istnieją również różnice pomiędzy oczekiwaniami grupy obcokrajowców i przedstawicieli społeczeństwa przyjmującego. W prywatnych obszarach życia imigrantów często dominują na interakcje z rodziną i bliższymi przyjaciółmi członkami grupy własnej (oczywiście taka grupa może z czasem stać się 
również kręgiem międzykulturowym). Oczekuje się, że imigranci będą starali się utrzymać swoją kulturę pochodzenia w sferze prywatnej (np. rodzina może oczekiwać, że imigranci podtrzymają tradycję świąteczną w domu, przyjaciele mogą zachować własne zwyczaje i pielęgnować je w mniejszym gronie). Dlatego możemy obserwować preferencję dla integracji lub separacji jako strategii utrzymania własnej tożsamości w grupie imigrantów. Ci sami imigranci mogą jednak preferować asymilację, na przykład w obszarze zawodowym, w związku z wymaganiami miejsca pracy, które powinny być zgodne z systemem społecznym, prawnym i kulturowym powszechnym w nowym otoczeniu.

Z punktu widzenia grupy większościowej wsparcie dla imigrantów wutrzymaniu ich własnej kultury może być słabsze, czasem nawet postrzegane jako symboliczne zagrożenie dla wartości lub kultury reprezentowanej przez społeczeństwo goszczące. W sferze publicznej społeczeństwo przyjmująceoczekuje na ogół zdecydowanej asymilacji imigrantów (np. zasady bezpieczeństwa zmuszające studentów do odkrywania twarzy na większości europejskich uniwersytetów). Prywatne sfery mogą być postrzegane przez społeczeństwo większościowe, jako te, w których integracja imigrantów (zachowanie ich własnego dziedzictwa przy jednoczesnym przyjęciu nowych obyczajów) byłaby preferowana (Ibidem).

Zaawansowane badania z dziedziny psychologii międzykulturowej wykazały, że preferencje dotyczące akulturacji (wśród przedstawicieli większości i w grupach mniejszościowych) zależą od wielu zmiennych. J edną z nich jest poziom napięcia między dwiema grupami, zwłaszcza związany z uprzedzeniami. Brytyjskie badania dotyczące preferencji w zakresie akulturacji i uprzedzeń etnicznych (np. Zagefka et al. 2012) sugerują, że przedstawiciele społeczeństwa przyjmującego, którzy preferowali integrację imigrantów, byli mniej uprzedzeni wobec nich i wykazywali mniejszą stronniczość w swoich ocenach i postawach. Silnie uprzedzeni przedstawiciele grupy dominującej nie życzą zaś sobie integracji imigrantów. W niniejszym artykule proponujemy spojrzenie 
na Brexit jako na bardzo silny głos społeczeństwa przyjmującego przeciwko integracji - tak silny, że duża część brytyjskiego społeczeństwa wolała zdezintegrować się z UE.

Brytyjskie społeczeństwo przyjmujące i immigration fatigue

W proponowanym ujęciu analizujemy zjawisko Brexitu zakładając, że akulturacja jest procesem dwustronnym, polegającym na wzajemnym wpływie obu grup kulturowych na siebie, powinniśmy zatem usłyszeć głosy dwu stron: rdzennej społeczności brytyjskiej, a także polskich imigrantów w UK. W dalszych częściach tekstu odwołujemy się do danych pochodzących z badań własnych prowadzonych wśród przedstawicieli polskiej społeczności wWielkiej Brytanii. Zacznijmyjednak od głosu Brytyjczyków - od krótkiego przeglądu literatury, analizującego powody oddania głosu Remain lub Leave w referendum z 23 czerwca 2016.

Aby zrozumieć psychologiczne konsekwencje głosowania na Brexit, warto przeanalizować klimat emocjonalny, panujący w Wielkiej Brytanii przed i tuż po głosowaniu. J ak opisuje David Coleman (2016, s. 681): „Większość finansistów ostrzegała przed poważnymi negatywnymi konsekwencjami odejścia z UE: dziesięciu uhonorowanych nagrodą Nobla ekonomistów potwierdzało te obawy, podobnie Madame Lagarde z MFW, OECD, Goldman Sachs, George Soros i inni - brytyjski kanclerz skarbu George Osborne (obecnie były kanclerz) rysował szczególnie ponury obraz, mówiąc o potrzebie natychmiastowego zastosowania środków nadzwyczajnych, by zabezpieczyć kraj przed upadkiem gospodarczym w przypadku głosowania Leave. Wszyscy przywódcy krajów UE zgodzili się z takim poglądem, podobniejak premier David Cameron i większość jego gabinetu, większość członków brytyjskiego parlamentu, wszyscy żyjący byli premierzy Wielkiej Brytanii, 13 byłych sekretarzy stanu USA i były szef CIA. Pięciu byłych szefów NATO i większość byłych szefów bezpieczeństwa Wielkiej Brytanii ostrzegało przed osłabieniem 
bezpieczeństwa w Europie po Brexicie, a większość poważnej prasy była zdecydowanie za głosowaniem Remain. J ednak brytyjski elektorat zagłosował za Brexitem, przytłaczającą większością 1,3 miliona głosów”.

Ta część brytyjskiego społeczeństwa, która popierała stanowisko Remain, popierała też argumenty związane z tym, że pozostanie w UE przyniesie korzyści gospodarce, podtrzyma inwestycje międzynarodowe, a także przyczyni się do wzmocnienia pozycji Wielkiej Brytanii jako globalnego gracza. Pozycja Wielkiej Brytanii w UE była bardzo korzystna: członkostwo w UE na skonsolidowanym rynku, ale bez strefy Schengen i euro. Generalnie zwolennicy pozostania w Unii koncentrowali się na ekonomicznych i międzynarodowych przesłankach utrzymania członkostwa w UE.

Podtekst kampanii „Remain” był bardziej racjonalno-strategiczny niż emocjonalny. Postępowanie racjonalne jest z pewnością właściwym podejściem do ważnych decyzji wpływających na przyszłość współczesnego świata, gospodarki i polityki, a także na psychologiczny klimat stosunków międzynarodowych i globalnej ekonomii. Niezależnie jednak od tego, jak istotne są myślenie strategiczne, rozsądek i ekonomia, nie są one zbyt dobrymi „czynnikami sprzedaży” w politycznej kampanii marketingowej. Emocje, szczególnie silne emocje, takie jak strach czy obawa przed przejmowaniem przez imigrantów miejsc pracy i świadczeń socjalnych, są o wiele bardziej „interesujące” z punktu widzenia spin doktorów. „Stabilna gospodarka i inwestycje” nie są tak stymulujące dla wyobraźni jak „fale imigracyjne” - kluczowy element kampanii „Leave” (Coleman 2016). Gietel-Basten (2016, s. 674) dość obrazowo podsumował emocjonalne natężenie kampanii „Remain": "Postawa skrajnie lewicującego Jeremy'ego Corbyna, lidera opozycyjnej Partii Pracy, wyróżniała się brakiem wigoru".

Według Colemana (2016) zjawiska opisywane wcześniej w połączeniu ze wzrostem natężenia imigracji, zarówno w statystykach, jak i oczach opinii publicznej, stały się ważnym czynnikiem wpływającym na wynik 
referendum brexitowego. W 2004 r. rząd brytyjski zezwolił na swobodny dostęp do pracy ośmiu wschodnioeuropejskim krajom (A8), gdy tylko przystąpiły do UE. Liczba osób pochodzenia obcego urodzonych wWielkiej Brytanii wzrosła z 95000 do 643000 po akcesji do UE wroku 2004 (Coleman 2016). W roku 2004 w Wielkiej Brytanii mieszkało 170000 osób pochodzących z Europy Wschodniej. Do 2013 roku było to 1,24 miliona osób. To największy napływ w historii Wielkiej Brytanii. W obliczu takiej liczby osób napływowych, gospodarcze planowanie strategiczne i dostosowanie prawodawstwa stały się bardzo trudnymi, a czasem niemożliwymi do zrealizowania zadaniami administracji rządowej. Stąd pojawiające się na dużą skalę problemy w systemie szkolnictwa, problemy mieszkaniowe i związane z niezwykle ważnym dla Brytyjczyków NHS (Narodowy System Zdrowia) - wszystkie one dość głośno obecne w mediach (patrz: Coleman, 2016). Gietel-Basten (2016) wskazuje, że decydenci znają plusy i minusy imigracji, jednak populiści mają tendencję do podkreślania wad. „Kiedy narracja krytyczna wobec imigracji zostanie utworzona i osadzona w szerszej narracji, dotyczącej kruchości infrastruktury i usług publicznych, potrzeby zaciskania pasa i zagrożeń tożsamości narodowej (...) bardzo trudno jest ją jakkolwiek przekształcić" (Gietel-Basten 2016, s. 674).

Matthew Goodwin i Caitlin Milazzo (2017) przedstawili wyniki opisujące kluczowe predyktory głosowania na Brexit: przyrost imigracji na poziomie lokalnym i nastroje dotyczące kontroli nad imigracją. Te dwie zmienne okazały się najważniejszymi czynnikami głosowania za Brexitem, nawet po uwzględnieniu czynników podkreślanych przez szeroko upowszechnione teorie głosowania eurosceptycznego. Jak proponują autorzy: „duży rezerwuar poparcia dla opuszczenia UE, a być może szerzej antyimigracyjny populizm, pozostanie w Wielkiej Brytanii, dopóki imigracja pozostanie istotną kwestią" (Ibidem, s .450).

Poloniajest ważnym uczestnikiem wzrostu populacji Wielkiej Brytanii. Wśród młodych matek spoza Wielkiej Brytanii Polki zajmują obecnie 
pierwsze miejsce (22 928 urodzeń), więcej niż Pakistanki (17342) i Hinduski (13 780) (Coleman 2016). Fakty te budują swoistą platformę narracyjną, związaną z głosami na temat „przeludnienia” w Wielkiej Brytanii.

Gietel-Basten zauważa, że jednym z efektów głosowania za Brexitem była „fala przemocy wobec obcokrajowców (głównie wymierzona w Polaków), której nie doświadczano od dziesięcioleci (...)” (Gietel-Basten 2016, s 673). Ten sam autor wspomina, że „obywatele UE niebędący obywatelami brytyjskimi wWielkiej Brytanii i Brytyjczycy przebywający na kontynencie w ramach emigracji, obawiając się zakłóceń w ich życiu i karierze" (Ibidem, s. 673)

Czynniki omówione powyżej, a także zmiany kulturowe i etniczne w strukturze społeczeństwa brytyjskiego, powodują szybkie i nie zawsze popularne zmiany w Ye Olde England (jakkolwiek by ową Starą Anglię definiowano). Zjednej strony brytyjskie społeczeństwo spotyka się z problemami mieszkaniowymi lub NHS, z drugiej jest faktem, że w roku 2011 anglosaska brytyjska populacja Londynu stanowiła mniej niż połowę (44\%) całej populacji Londynu - czyniąc brytyjskich Anglosasów mniejszością w ich własnej stolicy (Coleman 2016). Nic dziwnego, że zjawisko immigration fatigue mogło pojawić się wśród obywateli Wielkiej Brytanii.

Polacy w Wielkiej Brytanii po Brexicie - rzeczywistość akulturacji

Ponury obraz Wielkiej Brytanii po Brexicie, malowany przez noblistów i polityków - zwolenników głosowania Remain - nie był wystarczający, aby powstrzymać wyborców przed wyborem opcji Leave. Mógł on jednak znaleźć oddźwięk psychologiczny wśród tych, którzy nie mogli głosować, ale ich przyszłość była silnie uzależniona od wyniku referendum - imigrantów w Wielkiej Brytanii. W związku z tym wśród polskiej społeczności w Zjednoczonym Królestwie pojawiły się różnego rodzaju obawy. Aby przeanalizować te obawy i klimat psychologiczny wśród polskich 
imigrantów, Psychologowie z Polskiego Uniwersytetu na Obczyźnie (PUNO) w Londynie zaprojektowali program badawczy: „Polacy w Wielkiej Brytanii podczas Brexitu".

Poniżej przedstawiamy wybrane wnioski z bardzo obszernego raportu badawczego Brexit and Polonia: Challenges facing the Polish Community during the process of Britain leaving the European Union (Czubińska at al. 2018)

Badania nastrojów Polonii w UK - skrócony raport badawczy

W zaprojektowanych badaniach wzięło udział 617 respondentów. 56\% to osoby w wieku 35-49 lat; 63\% to osoby, które przybyły do Wielkiej Brytanii w latach 2004-2010. 49\% respondentów posiada wykształcenie wyższe, 51\% to osoby z wykształceniem średnim. $71 \%$ to osoby zatrudnione na stałe, na podstawie kontraktu.

W celu przeprowadzenia badania stworzono kwestionariusz on-line z pytaniami otwartymi i wielokrotnego wyboru.

Skrócony przegląd wyników

Pierwsza część badania pokazała najważniejsze zagadnienia, związane z obawami dotyczącymi skutków Brexitu, wśród polskich imigrantów w Wielkiej Brytanii. Najpopularniejsze stwierdzenia dotyczą trudności w podróżowaniu pomiędzy Wielką Brytanią a Unią Europejską (ponad 80\% respondentów wskazało tę kwestię), a także ogólne przewidywanie „powszechnej straty” w wyniku Brexitu (ponad 80\% odpowiedzi). Polscy badani spodziewają się problemów z zatrudnieniem w Wielkiej Brytanii, agresywnych nastrojów i zachowań wobec Polaków w Wielkiej Brytanii, ogólnych trudności w relacjach z obywatelami brytyjskimi, a także pro- 
blemów w korzystaniu z usług brytyjskie służby zdrowia (National Health System - NHS). Pozostałe stwierdzenia i szczegółowe dane zostały przedstawione w naszym artykule (2018).

Zapytaliśmy naszych respondentów o ich decyzje dotyczące powrotu do Polski po referendum brexitowym. Ogromna większość Polaków deklaruje planowany powrót do Polski po roku 2020. Połowa badanych twierdzi, że pozostanie w tej chwili w Wielkiej Brytanii, jedna trzecia jest niezdecydowana.

W badaniu pytaliśmy o oczekiwania polskiej społeczności, która pozostanie w Wielkiej Brytanii. J akiego rodzaju pomocy oczekują Polacy od rządu brytyjskiego? Przede wszystkim nasi respondenci twierdzą, że biurokracja jest główną przeszkodą w procesie uzyskiwania prawa stałego pobytu. Dlatego ponad 80\% respondentów doceniłoby pomoc w procesie ubiegania się o rezydenturę, także ponad 80\% wskazało na potrzebę tworzenia źródel informacji (telefony informacyjne, media), pomoc w problemach biznesowych zostałyby doceniona przez prawie o 80\% respondentów, istotną jest też pomoc w rozwiązywaniu problemów edukacyjnych dzieci, respondenci chcieliby również otrzymać wsparcie w procesie pozyskiwania świadczeń socjalnych wWielkiej Brytanii.

Powrót do Polski wydaje się trudną decyzją. Zdaniem prawie 70\% uczestników badania, ważnym problemem jest przewidywany spadek wynagrodzenia. Respondenci są również zaniepokojeni przewidywanymi niższymi standardami życia, brakiem możliwości zatrudnienia, sytuacją polityczną w Polsce, problemami mieszkaniowymi w Polsce i problemami edukacyjnymi dzieci.

Oczekuje się, że polski rząd zapewni wsparcie wrozwiązywaniu problemów związanych z opieką zdrowotną, problemami z zatrudnieniem, pomocą socjalną, problemami mieszkaniowymi, problemy z uruchamianiem własnej działalności, problemy z przekwalifikowaniem. Prawie 60\% respondentów woli, aby ich dzieci kontynuowały edukację w Wielkiej Brytanii. Prawie 50\% zgłasza potrzebę skorzystania z zajęć wyrównawczych, 
które wydają się konieczne po powrocie dzieci do polskich szkół. Polscy respondenci oczekują także wyrównawczych lekcji języka polskiego dla dzieci wracających z Wielkiej Brytanii.

Zbadaliśmy wpływ poziomu wykształœenia respondentów na spektrum obaw dotyczących Brexitu wśród Młodej Polskiej Emigracji w Wielkiej Brytanii. Otrzymane dane sugerują, że respondenci z wyższym wykształceniem (studia uniwersyteckie) postrzegają Brexit jako mniej wpływający na ich życie w porównaniu z Polakami o niższym poziomie wykształcenia (wykształcenie zawodowe i średnie). Zbadaliśmy również związek między płcią respondentów i obawami dotyczącymi skutków Brexitu wśród polskich imigrantów w Wielkiej Brytanii. Kobiety znacznie częściej niż mężczyźni zwracają uwagę na oczekiwane negatywne efekty Brexitu.

Wnioski i podsumowanie

Celem powyższego opracowania było wskazanie na niezwykle istotny moment ewolucji procesów akulturacyjnych we współczesnej Europie. Brexit wydaje się być momentem, w którym Wielka Brytania zdecydowała się pójść raczej w kierunku strategii Separacji niż Integracji w termach używanych przez model RAEM. Zarówno w przestrzeni publicznej, jak i prywatnej oraz w dwóch grupach - rdzenni Brytyjczycy i mniejszościowi imigranci polscy - możemy opisać podobne wzorce postępowania, związane ze wzrostem niepokoju obu grup przechodzących przez wzajemną akulturację. Brytyjskie społeczeństwo obawia się, że system edukacji, a także NHS, nie wytrzymają natężenia imigracji.

Szybka i istotna zmiana kulturowa również nie wydaje się być dobrze odbierana przez głosujących za Brexitem Brytyjczyków. Polscy imigranci podobnie jak Brytyjczycy wyrażają zaniepokojenie problemami wychowawczymi i szkolnymi dzieci, a także problemami z systemem opieki zdrowotnej i obniżeniem standardu życia. 
J ak wspomniano wcześniej, analiza złożonych i wielowymiarowych procesów akulturacji powinna być prowadzona w wielu obszarach, w których zmieniają się obie kultury (publiczne i prywatne, polityczne, zawodowe, ekonomiczne, rodzinne, społeczne, religijne i poznawcze). Na wszystkich tych obszarach ważne jest poszukiwanie rozwiązań pomagających znaleźć wspólną płaszczyznę między większością, a imigrantami. Obie strony wydają się wyrażać podobne troski i obawy. Teoretycznie więc porozumienie powinno być możliwe - skoro rozumiemy obawy partnera, bo sami mamy podobne, jakżełatwo powinniśmy dojść do porozumienia - czyż nie? J ednak to, czy taka empatyczna wymiana jest możliwa, wymaga pogłębionych, dalszych badań.

Bibliografia

Berry J.W. (1990), Psychology of acculturation, [w:] Current theory and research in motivation, (Ed.) Berman J.J., Vol. 37, Nebraska Symposium on Motivation, 1989: Cross-cultural perspectives, University of Nebraska Press, Lincoln

Berry J.W. (2005), Acculturation: Living successfully in two cultures, “International J ournal of Intercultural Relations” Vol. 29, Iss. 6 Berry J.W. (2006), Contexts of acculturation, [w:] Cambridge handbook of acculturation psychology, (Eds.) Sam D.L., Berry J.W., Cambridge University Press, New York

Bourhis R.Y., Moïse L.C., Perreault S., Senécal S. (1997), Towards an interactive acculturation model: A social psychological approach, “International J ournal of Psychology" Vol. 32, Iss. 6

Coleman D. (2016), A Demographic Rationale for Brexit, "Population \&Development Review” Vol. 42 Iss. 4

Czubińska G., Łużniak-Piecha M., Golińska A., Kulczyk J. (2018), Should we stay or should we go? Poles in the UK during the Brexit. 
Research report, [w:] Brexit and Polonia: Challenges facing the Polish Community during the process of Britain leaving the European Union, (Eds.) Fleming M., Taborska H., London, PUNO Press [wdruku]

Gietel-Basten S. (2016), Why Brexit? The Toxic Mix of Immigration and Austerity, "Population \&Development Review” Vol. 42 Iss. 4 Goodwin M., Milazzo C. (2017), Taking back control? Investigating the role of immigration in the 2016 vote for Brexit, "British J ournal of Politics \& International Relations" Vol. 19 Iss. 3

Harris J . (2016), Britain is in the midst of a working class revolt, "The Guardian" 17 June, https://www.theguardian.com/commentisfree/ 2016/jun/ 17/ britain-working-class-revolt-eu-referendum

Horenczyk G., J asinskaja-Lahti I., Sam D.L., Vedder P. (2013), Mutuality in Acculturation. Toward an Integration, "Zeitschrift für Psychologie” Vol. 221, Iss. 4

Łużniak-Piecha M., Witkowski S.A. (2007), Style radzenia sobie z szokiem kulturowym $w$ przedsiębiorstwach globalnych. Aspekty metodologiczne badań interkulturowych, „Zarządzanie Zasobami Ludzkimi” nr 2

Navas M., García M.C., Sánchez J ., Rojas A.J ., Pumares P., Fernández, J.S. (2005), Relative Acculturation Extended Model (RAEM): New contributions with regard to the study of acculturation, "International J ournal of Intercultural Relations” Vol. 29, Iss. 1

Navas, M.S., Rojas A.J., García M.C., Pumares P. (2007), Acculturation strategies and attitudes according to the relative acculturation extended model (RAEM): The perspectives of natives versus immigrants, "International J ournal of Intercultural Relations" Vol. 31, Iss. 1 Piontkowski U., Rohmann A., Florack A. (2002), Concordance of acculturation attitudes and perceived threat, "Group Processes and Interpersonal Relations” Vol. 5, Iss. 3 
Rivera F.I., Burgos G. (2010), The Health Status of Puerto Ricans in Florida, "Centro J ournal" 22(1)

Rojas A.J ., Navas M., Sayans-J imenez P., Cuadrado I. (2014), Acculturation Preference Profiles of Spaniards and Romanian Immigrants: The Role of Prejudice and Public and Private Acculturation Areas, "The J ournal of Social Psychology" 154 (4)

Schwartz S.J ., UngerJ .B., Zamboanga B.L., SzapocznikJ . (2010), Rethinking the concept of acculturation, "American Psychologist" 65(4)

Zagefka H., Tip L., González R., Brown R., Cinnirella M. (2012), Predictors of majority members' acculturation preferences: Experimental evidence, “J ournal of Experimental Social Psychology” Vol. 48, Iss. 3 